\title{
Discussion on How to Improve the Comprehensive Ability of Students in Vocational English Teaching
}

\author{
Y. WU \\ University of Science and Technology, Liaoning 114051, China
}

\begin{abstract}
This paper analyzes the two main factors that influence the higher vocational college students' comprehensive ability to use English, teaching and learning. This paper focuses on the methods of improving the students' ability and offers some effective suggestions combined with the author's practice in teaching. These methods include, to train teachers more effectively in order to help them form a correct teaching attitude and teaching method, to select suitable teaching materials, to reform assessment methods. As for the students, they are supposed to set a clear aim and correct attitude towards study, improve their learning methods and efficiency.
\end{abstract}

KEYWORD: Higher vocation; English teaching; Comprehensive ability; Cultivate

Foreign language teaching in our country attaches too much importance to the examination function for a long time, so quick thinking is more serious. Blindly pursuing the examination results have caused English teaching to stay in the exam oriented education level. Although higher vocational colleges have been already aware of the problem, the teachers still mostly focus on imparting knowledge and skills, ignoring improving the students' comprehensive ability, which is not consistent with the fundamental task in higher vocational colleges.

\section{THE CAUSE OF THE STUDENTS' POOR COMPREHENSIVE ABILITY TO USE ENGLISH IN HIGHER VOCATIONAL COLLEGES}

The learning process is completed by the two aspects of teaching and studying in common, so analyzing the reason also can be from these two aspects.

\subsection{Teaching aspects}

\subsubsection{The mode of oriented education}

In the long-term exam oriented education mode, getting good grades has become the main purpose of teaching. The teachers even like combining the teaching content with specific topic, do not let go of each language point, make the good text fragments, causing students only to pay attention to remembering how many words they recite, to learn what kind of grammatical knowledge, and to get used to memorizing every detail but not to use them freely. Teachers will study the answer skills and regard it as the focus of teaching, neglecting the cultivation of students' comprehensive quality.

\subsubsection{The problem of Teachers}

According to the characteristics of higher vocational school, English education not only demands students to master the basic English skills, but students are required to master his necessary professional skills on future occupation and post in English.[1] However, the current vocational college English teachers mostly graduated from normal university English majors, although after a "double teacher type" training of teachers, some teachers only learn about knowledge about other majors, it is far from what they should master thoroughly. Owing to the teachers' lack of professional knowledge, they often only concentrate on the foreign language learning, which resulted in the language teaching, though they could speak clearly, yet they cannot teach the professional knowledge.

\subsubsection{The problem of teaching mode and method}

The current mode of teaching is still a teachercentered traditional teaching pattern, that is, the teachers simply impart knowledge and skills.[2] In class, the teachers are the only source of knowledge and students can only passively accept, which ignores the development of the students' 
consciousness of initiative, participation and the practical ability, thus the students do not really play a main role in class. Besides, the single method of teaching, the boring teaching process, too much emphasis on rote learning various grammatical rules are the main reasons. And what's worse, that the teaching content can't be agreed with the actual work is very serious, and teaching puts emphasis on imparting knowledge, but not pay attention to cultivating the ability.

\subsection{Learning aspect}

\subsubsection{The learning objectives are not clear enough and the thought of long-term oriented educa- tion is not easy to change}

As a number of students don't have clear learning objectives, they don' have correct attitudes, and even some students do not make a clear plan for their future occupation after getting into the higher vocational colleges, they formed the wrong objective for the final exam rather than cultivate the comprehensive quality. This situation will inevitably lead to the fact that the majority of the students in learning pays more attention to what kind of knowledge points are more likely to appear in the final paper and how to make the answers to these questions according to some skills., but they rarely think about obtaining other aspects of knowledge through study and improving their own comprehensive ability to use knowledge.

\subsubsection{Problems in students' learning methods}

Rote learning is frequently used English learning method by Chinese students while the low efficiency of this method is well known, but after many yeas' of teaching reform and Practice, there are still plenty of students who learn by memorizing. This is because the students did not find a better way to deal with the English learning.

\section{HOW TO IMPROVE STUDENTS' ENGLISH COMPREHENSIVE ABILITY}

To improve the comprehensive, applicable ability of the students, we should also start from the two aspects of teaching and learning.

\subsection{Strengthen the training of teachers, form correct teaching ideas and teaching methods, appropriately choose the current general teaching material, reform examination methods, and solve the teaching problems}

\subsubsection{The construction of "double teacher type"}

The construction of the teaching staff is essential to the development of the school, the construction of "double teacher type" is the key to improving the teaching quality of higher vocational education, but is also the basis of the survival and development of Higher Vocational colleges. It's vital that we should establish and cultivate a team of staff who are competent and excellent, well-organized, professional and part-time, with innovative spirit and we should give the priority to having a team of staff with the relatively stable "double teacher type" in higher vocational education, which is the fundamental guarantee of the quality of the higher vocational education. Essential characteristics of the occupation, education, vocational college English teachers should have a general education in addition to the qualification of teachers, but they also should have and are engaged in the teaching work to adapt to the practical work experience or have a corresponding professional and technical level.[3]

\subsubsection{Reform of Teaching Method}

Completely change the wrong ideas that students learn in order to test, we should regard improving their comprehensive quality, and adapting to the future developmental need as intrinsic motivation. At present, there is a part of the students in higher vocational colleges who have such a concept: "It makes no difference whether they learn English well or not, but they think that the key is to learn the professional course, anyway they will not use English in the future work." This concept leads to the fact that a lot of students are just satisfied with the final exam scores, and even some students are boning up on it at the end of the semester, to make matters worse, some students wait for the approximate range about the final exam that English teachers give. As we know, English, as a language, it is impossible to master it through the short-term assault. Of course, this wrong idea must be abandoned.

\subsubsection{English textbooks}

English teaching as the core materials for English teaching, English class is important for good, but driven by economic interests press tend to publish general materials, repeat printing lots of would bring economic benefits, rather than publishing to different professions even similar professional English teaching materials.[4] This situation requires teachers in the teaching process of teaching content to have a choice, appropriate to increase the learning professional knowledge related to the students to explain the strength. The teaching material is the most important teachers in the teaching process of reference, but not the only data. In the current higher vocational English teaching material cannot fully meet the needs of teachers and students under the condition of appropriate, recommend to the students and professional related English data should be, also is essential. 


\subsubsection{The reform of examination method}

According to the conditioned reflex theory, we can know if we want a conditioned reflex to be subtractive, we will gradually decrease the the stimulus of the conditioned reflex, that is, to reduce the inevitable link between learning and test method, to change the reform of examination mode, to increase the students' testing frequency, strengthen the usual assessment.[5] Meanwhile, we have to reinforce the other condition in order to form another conditional reflex, in other words, teachers encourage the students to apply learned English knowledge to professional learning, thus enable students to obtain the experience of success in the process of application, achieving motivation. Interest is the prerequisite to learn all the knowledge and skills, therefore students who are forced to rote learning and acquire their own wanted knowledge with pleasure must caused different results.

\subsection{To establish correct learning objectives, correct attitude towards learning, improve learning method, improve learning efficiency, and solve problems to learn}

\subsubsection{Occupation planning}

Students should se their occupation objectives with the help of the teachers as soon as possible the moment they go into the higher vocational colleges. Having had a clear understanding of the future occupation and profession, students will also determine the learning objectives and of course, their learning attitudes will become more positive. At present, English has penetrated into every corner of our work, study and life, so no matter what kind of occupation you take up, English can not be completely separated from reality. After students have made a plan for their own future occupation, they will naturally regard learning English as a basic subject of their comprehensive qualities.

\subsubsection{Change the test, ideas and improve the com- prehensive quality}

What teachers should do is to completely change the wrong idea that students learn in order to test and to consider improving their comprehensive quality, adapting to the future developmental need as intrinsic motivation. At present, there is a part of the students in higher vocational colleges who have such a concept: "It makes no difference whether they learn English well or not, but they think that the key is to learn the professional course, anyway they will not use English in the future work." This concept leads to the fact that a lot of students are just satisfied with the final exam scores, and even some students are boning up on it at the end of the semester, to make matters worse, some students wait for the approximate range about the final exam that English teachers give. As we know, English, as a language, it is impossible to master it through the short-term assault. Of course, this wrong idea must be abandoned.

\subsubsection{Pay attention to the training of practical ability}

Change the simple mode of operation that the students listen in class and complete homework after class. What students should do is to search lots of information related to their majors and constantly improving the efficiency of learning. To strengthen the English learning, students must completely change the wrong method of only remembering the words and the grammatical rules in English learning English, promoting students' comprehensive ability of "listening, speaking, reading, writing and translation", paying attention to practical ability training to lay a solid foundation for success.

\section{CONCLUSIONS}

In short, in order to make English teaching more effective, teaching and learning should be in close cooperation with each other, which is every crucial. Only when the teachers and students have a consistent understanding of teaching and learning and strengthen the interaction between teachers and students, can we improve the students' comprehensive ability.

\section{REFERENCES}

[1] X.Q. ZHANG. The higher vocational English education based on the competency. Education and Vocation.2010, 23.

[2] J. SONG. The existing problems and Countermeasures of English Teaching in higher vocational colleges. Vocational and Technical Education, 2010, 11.

[3] T. DENG, L.G. WANG. The existing problems and Countermeasures of English Teaching in higher vocational colleges. Education and Vocation, 2010, 21.

[4] L. ZHANG. A discussion and suggestions on the current situation of English Teaching in higher vocational education. Modern Business Trade, Industry, 2010, 2(187).

[5] Z.Q. WENG. Suggestions on the trend of Higher Vocational English teaching. Occupation, 2011, 27. 